\title{
Anadolu'da İklime Bağlı Kıtlık Afeti ve Risk Yönetimi
}

* Sorumlu Yazar / Corresponding Author:

\section{Nehir VAROL ${ }^{*}$, Eda SELIMOĞLU ${ }_{\oplus}$, Timur GÜLTEKIN ${ }^{3}$}

' Dr. Öğr. Üyesi, Acil Durum ve Afet Bölümü, Ankara Üniversitesi, Ankara / TÜRKiYE

${ }^{2}$ Öğr. Görevlisi, Otel, Lokanta ve İkram Hizmetleri Bölümü, Ankara Üniversitesi, Ankara / TÜRKIYE

${ }^{3}$ Prof. Dr., Antropoloji Bölümü, Ankara Üniversitesi, Ankara / TÜRKIYE
Alındı/Received: 13 Mart / March 2019 Düzeltildi/Revised: 6 Mayıs / May 2019

Kabul/Accepted: 7 Mayıs / May 2019 Yayımlanma/Published: 12 Haziran / June 2019

Climate Related Famine Disasters in Anatolia and Risk Management

\section{$\ddot{\mathrm{O} z}$}

Afet, ekonomik ve sosyal kayıplara neden olan, sosyal hayatı kesintiye uğratan ve ani olarak gelişen ve yerel kapasite ile üstesinden gelinemeyen olaylar olarak tanımlanır. Doğa kaynaklı ya da insan/teknoloji kaynaklı afetler aynı zamanda yavaş gelişen ve ani gelişen afetler olarak da sınıflandırılmaktadır. İklim değişiklikleri, kuraklık, çölleşme ve bu süreçlere bağlı olarak gelişen kıtlık afeti de yavaş gelişen afetler sınıfında değerlendirilebilir. Dünya coğrafyasının birçok bölümünde insanoğlunun varoluşundan bu yana yaşanan kıtlık afeti dönem dönem Anadolu topraklarında da etkili olmuştur. Kıtlık, uzun süre yiyecek yetersizliğinin bir sonucu olarak ortaya çıkar. Yağışların azlığı ile su kaynakları azalmaya başlar ve kuraklığın etkisi artmaya başlar. Kıtlık, açlık ve susuzluk ciddi sonuçlara neden olabilir. Anadolu tarihi dönemler boyunca, özellikle yağışların azlığı ve çekirge istilaları nedeniyle kıtlık afetine maruz kalmıştır. Hatta efsaneler, destanlara konu olan önemli kıtlıklar göç olgusunu da beraberinde getirmiştir. İnsan göçü, din, kültür, ekonomi, savaş, terör ve afet gibi faktörlerle gerçekleşmektedir. Genellikle bu göçler zorunlu nedenlerle ortaya çıkmıș, yiyecek bulma arayışından ya da diğer türden afetlerden kaynaklanmıştır. Kuraklık ve buna bağlı oluşan kıtlık iklim değişikliklerinin hızlanması ile artış göstermektedir. Bu çalışmada kıtlık afeti kavramı, türleri, tarihte yaşanan kıtlık olayları anlatılmış ve kıtlık afetine karşı alınabilecek önlemler ve risk yönetimi tartışılmıştır.

Anahtar Sözcükler: Kıtlık Afeti, Kuraklık, Afet Yönetimi, Anadolu'da Kitlik

\section{Giriş}

\section{Kıtlık Kavramı}

İklim değişikliklerin en önemli sonuçlarından birisi olarak gösterilen kuraklığın, farklı disiplinler için farklı tanımlarımevcuttur. Genelolarak kuraklık, suihtiyacinın karşılanamaması durumu olarak tanımlanabilir. Sosyal bilimciler ise, kuraklı̆̆ın açlık işsizlik, göç gibi sosyoekonomik etkileriyle ilgilenmektedirler (Kadıoğlu, 2012). Afet sınıflamasında kuraklık genellikle yavaş gelişen ve tahmini zor, etkisi geniş bir afet türüdür. Günümüzün en büyük sorunlardan birisi olan kurakllk,

\section{Abstract}

Disasters are defined as sudden disruptions to the functioning of a community or a society at any scale that cannot be overcome by the local capacity. Disasters are also classified as natural or technological/ human-made or as slow onset and rapid onset disasters. Climate change, drought, desertification and famine disaster due to these processes can be considered slow onset disasters. In many parts of the World since the existence of humanity, the famine has been effective. Scarcity emerges as a result of long-term food shortages. With the lack of rainfall, water resources begin to decrease and the effects of drought starts to increase. Famine, bunger and thirst can cause serious consequences. Throughout history, Anatolia was exposed to famine disasters, particularly due to the lack of precipitation and grasshopper infestation. In fact, legends and important famines that became subjects to epics have brought the phenomenon of migration. Human migration is realized by factors such as religion, culture, economy, war, terror and disaster. Generally, migrations are caused by searching for food in the past. drought and the increased famine with the acceleration of climate change. In this study, the concept of famine disaster, its types and the measures that can be taken against it are discussed along with the risk management.

Key Words: Famine Disaster, Drought, Disaster Management, Anatolian Famine çevreyi, kent yaşamını, sağlğ̆ı, kalkınmayı ve ekonomiyi etkilemektedir.

Kıtlık kavram olarak yaşamın devamı için gerekli olan mamullere bir şekilde ulaşamamak ya da bu mamullerin bir nedenden dolayı ortadan kalkması anlamina da gelmektedir. Temel nedeni yanginlar, depremler, çekirge istilaları, kuraklık, iklimin çok soğuk ya da çok sıcak olması gibi coğrafi faktörler olsa da sosyal ya da siyasi nedenler de kitlığa neden olabilmektedir (Aybar, 2017). Savaşlar, sosyal ve ekonomik düzeni olumsuz yönde etkileyen isyanlar, 


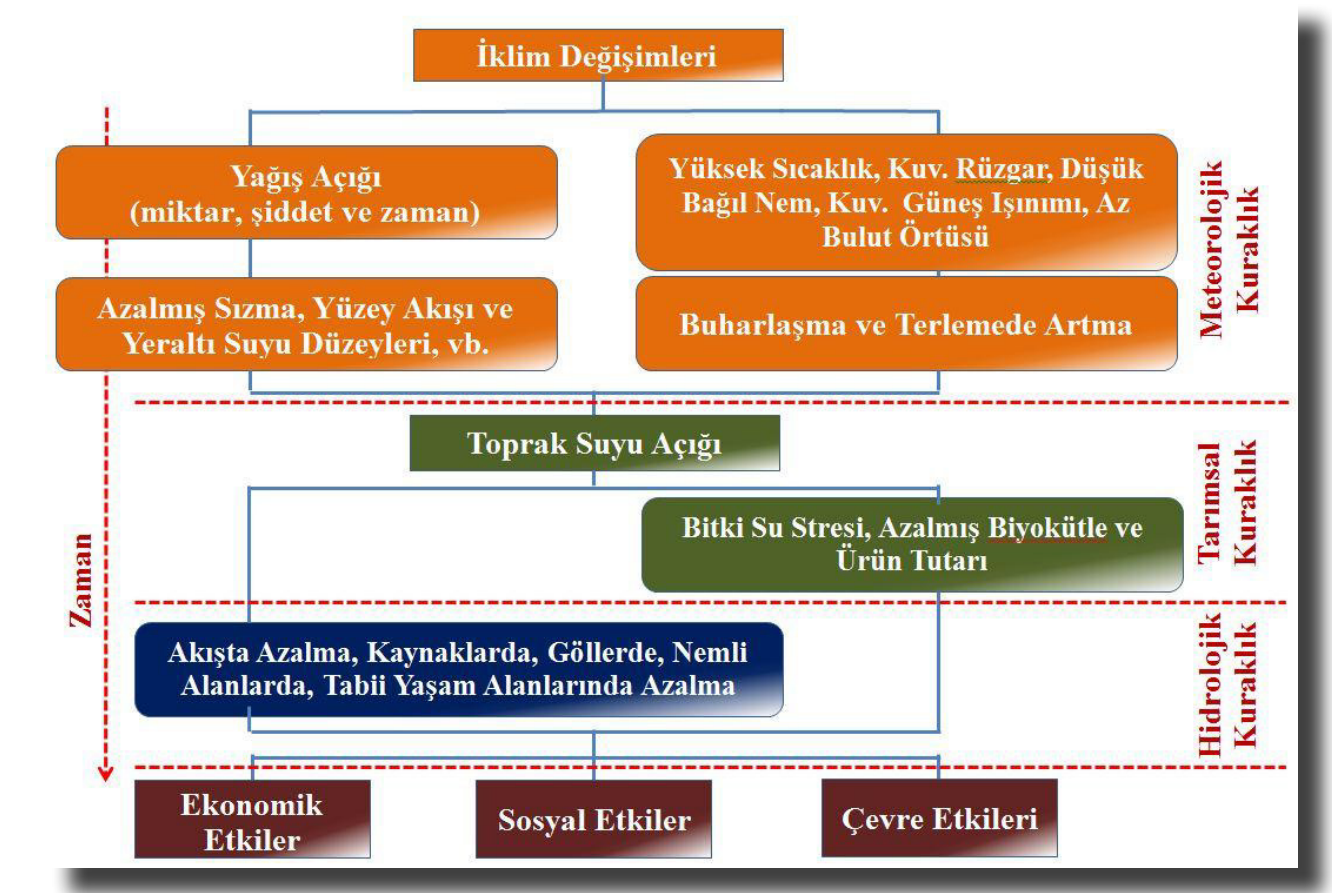

Resim 1. Kuraklık türleri ve iklim değişikliği etkileri (Ulusal Kuraklık Yönetimi Strateji Belgesi ve Eylem Plan1 2017-2023, URL 1).

kıtlı̆ga neden olabilecek siyasi durumlardır (Demir ve Aktaş, 2008).

Genel anlamda temel kuraklık türleri meteorolojik kuraklık, hidrolojik kuraklık ve tarımsal kuraklık olarak sinıflandırılabilir (Resim 1).

Yağış azlığ1 nedeniyle tarımdan istenilen düzeyde verim alınamaması ülkeleri ekonomik anlamda ciddi bir sıkıntıya sokabilmektedir. Örneğin 1987 yllı civarında muson yağmurlarının çok az yağması nedeniyle kıtlıkla yüz yüze gelen Hindistan, o güne kadar dişarıdan yardım almadan beslenme anlaminda kendi kendine yeten bir ülke durumunda iken kitlıktan sonra çok sayıda can kayıplarına sahne olmuştur (Standage, 2016).

Kitluğa neden olan faktörlerden biri de çekirge istilalarıdır. Çekirgelerin tarım arazilerini yok etmesinden dolayı açlık ve buna bağlı olarak kıtlık söz konusu olabilmektedir. Bu durumun ülke ekonomisine uğrattı̆g 1 en fazla zarar savaş dönemlerinde kaydedilmektedir. Özellikle 1916 yllında yok olup giden birçok tarla ve mahsul ülke ekonomisine oldukça zarara yol açmıştır (Yıldırım, 2014). Ülkemiz bu konuda oldukça sıkıntılı günler yaşamıştır. Farklı türlerde çekirge istilalarına geniş bir zaman aralığında yüz yüze kalmıştır. (Obuz, 2017).

Kitlık sürecini devamlı yaşayan insanlar hayatta kalabilmek adına kendilerince yöntemler geliştirmişlerdir. Yiyeceğe ulaşamadıklarından bitki veya bitki kökleri, hatta leş bile yiyerek yaşama tutunmaya çalışmışlardır (Sarköse, 2013).

Yaşanılan darlık ve kıtlık olaylarının toplumsal ve bireysel yönde oldukça olumsuz etkilerini gözlemlemek mümkündür. Aile üyelerinin bozulan ruh halleri nedeniyle, eşlerini ve çocuklarını para karşıllı̆ı kullanan aile reislerine tarihte rastlamak mümkündür. Aynı zamanda duruma çare bulamayan aile büyüklerinin intihar ederek kendi yaşamlarına son verdikleri bilinmektedir. Bunun yanında kıtlık kitlesel ölümler gibi daha büyük sonuçlar doğurmuştur (Karademir, 2013).

Tarihe baktığımızda XVI. yüzyllın ortasından itibaren Osmanlı ordularının sayısı giderek artmıştı ve yüzbinlerce insanın doyurulması ciddi bir çalışmayı gerektirmişti. Öncelikli olarak ordunun doyurulması ve savaş ya da barışta kıtlıkla karşı karşıya gelmemesi gerekmekteydi. Aksi takdirde hükümdarı konumundan edecek isyanlar çıkabilirdi (Onaran, 2016). Diğer yandan tarihe bakıldığında savaş zamanlarında ordular yiyeceklerini yanlarında pek taşımayıp güzergâhları üzerindeki yerleşim yerlerinden hem kendileri için hem de hayvanları için gıda temin etmekteydiler. Bu konu hem olumlu hem de olumsuz anlamda iki yönlü düşünülebilir. Çünkü askerlerin bir yerde uzun süre kalmaları kıtllğa neden olabilir. O nedenle orduların kendilerine yetecek kadar yiyecek depolaması gerekmektedir (Standage, 2016).

Çeşitli nedenlerden dolayı yiyecek bulamama yani kıtlık durumu çoğunlukla kendi mutfağını oluşturma ile sonuçlanabilir. Bu mutfağı ise daha önce tüketilmeyen yiyecekler oluşturmaktadır. Şehir yaşamında dışarıda bırakılan kedi ya da sıçan gibi hayvanlar kıtlı̆̆ın getirdiği mutfağa dâhil olan hayvanlar için örnek verilebilir. Hatta k1tlık dönemlerinde insan eti de yenildiği görülmektedir (Goody, 2013). 16. yüzyılda yaşanan kıtlıkta İngiltere'nin bazı bölgelerinde yaşayan insanların normal zamanların 
aksine bezelye, mercimek, yulaf, yaban darısı ve burçağa yöneldiği, k1tlı̆̆ın oluşturduğu yeni mutfağa verilebilecek örnekler arasındadır (Beşirli, 2017).

Yıllar arasında farklılık gösteren yağış koşullarına bağlı olarak, kurak geçen dönemler açlık ve kıtlık tehlikesine neden olabilmektedir. Çünkü tarımsal faaliyetler büyük oranda iklim koşullarına ve yağış miktarına bağlı olarak verimliliği etkilenmektedir. Afrika'nın Sahel Bölgesi, Hindistan ve Pakistan'da bu durum hemen hemen her yıl görülmektedir (Nişanc1 1987).

Kitlığa neden olan faktörlerin yanında kıtllğın da yol açtı̆̆1 durumlar arasında salgın hastalıklar ve birtakım aralıklarla veba salgınları sayılabilir (Montanari, 2018).

\section{Tarihte Önemli Kıtlık Olayları}

Insanlık tarihi kuraklıklar ile doludur. İklimde meydana gelen soğumaların MÖ 24. Yüzyılda başlayan ve Troia III'de etkili olan göçün ana nedeni olarak görülmektedir. Bunun bir sonucu olarak da büyük bir kıtlık yaşanabildiğine dair birçok araştırmacı hemfikirdir. Çünkü iklimsel anlamdaki soğumalar, bitki örtüsünü, hayvanları ve dolayısıyla insanların yaşam koşullarını sarsıcı derecede etkileyebilmektedir (Taşdöner 2012).

Birinci Dünya Savaşı toplumlar üzerinde ciddi tahribatlar oluşturmuştur. Özellikle Avrupa'da genç nüfusta önemli bir düzeyde kayıplar yaşanmıştır. İnsanlar bunun yanında evlerini ve şehirlerini terk etmek durumunda kalmışlardır. Tüketim artmış fakat diğer yandan üretim neredeyse durma noktasina gelmiştir. Bunun sonucu olarak da birçok ülkede ekonomi çökmüş, birçok ülke açlık, kıtlık ve hastalıklarla mücadele etmek zorunda kalmıştır (Baygıner, 2013).

İkinci Dünya Savaşı ilk savaş olan Birinci Dünya Savaşı'na oranla silahların, bombaların gücü anlamında daha da yıkıc1 olmuştur. Gida maddeleri karneyle bile bulunamiyordu. Otel ve restoranlarin hemen hemen hepsi kapanma noktasına gelmişti. Diğer yandan toplu yemek hizmetine olan ihtiyaç da giderek artmıştı (Gürsoy, 1995).

Amerika da gida konusunda karne uygulamas1 yapan ülkelerden birisidir. İkinci Dünya Savaş1 döneminde yaşanan açlık, halkı önemli ölçüde karışılığga sürüklemiştir (Baygıner, 2013). Ayrıca savaşın uzun süreceğini düşünerek, Amerika çok fazla stok yapmıştır. Hatta sonraki y1llarda et, peynir, süttozu, tereyağ1 ve buna benzer savaş stoklarını yardım adı altında, ülkemiz de dahil olmak üzere geri kalmış ya da gelişmekte olan ülkelere dağıtmak durumunda kalmıştır (Merdol ve Merdol, 2012).

Yunanistan da savaş sırasında büyük bir bozguna uğrayan ülkelerden birisidir. Tarım dâhil üretimin son bulması, ülkeye zor günler yaşatmıştır. Çiftliklerin tahrip edilmesi, hayvanların telef olmas1, ekecek tohumluk olmaması, balıkçılık dahi yapılmasına izin verilmemesi ve ambargo gibi nedenlerle açlık ve yetersiz beslenme nedeniyle savaşa karşı ülkedeki direnç kırılmaya çalış1lmıştır (Utkugün, 2016). Almanya ve İtalya tarafindan işgale uğrayan Yunanistan'da büyük çaplı açlık baş gösterdi. 2. Dünya Savaşı'nın yol açtı̆̆ı ortam nedeniyle gıda maddelerine yönelik talep arttı fakat üretim azaldı. Bu da büyük çaplı ölümlere, salgın hastalıklara ve kıtlığa yol açtı. Türkiye o dönemde Yunanistan'daki kitlığın etkilerini azaltmak amaciyla gida yardımında bulundu (Kalemli ve Erdem, 2011).

Kitlık afetine neden olan olaylar arasında iç savaş da ülkeler açısından oldukça ciddi çöküşlere yol açmıştır. İspanya'da 17 Temmuz 1936'da başlayan iç savaş sosyal yaşamı felce uğratmış, sayısız insan açlık ve kıtlıkla karşı karşıya kalmıştır. Anneleri ile birlikte hapse atılan çocukların bir kısmı yeterli düzeyde beslenemediği için yaşamlarını yitirmişlerdir. Tüketim maddelerinde görülen kıtlık sosyal yaşamı zorlaştırmıştır (Gökşsenli, 2013).

Savaşların genel olarak etkilerine bakıldığında, gida ve beslenme ile ilgili yetersiz durumlara yol açmasının yanında yüksek oranda fiyat artışlarına neden olabilmektedir. $\mathrm{Bu}$ da toplumun belli bir kesimini zengin eden karaborsacılığın ortaya çıkmasında etkilidir (Yilmaz, 2010).

Sovyetler Birliği 1990 yllında ekonomik bir kriz yaşadı. Ulusal gelirin oldukça düşmeye başlamasıyla birlikte bunun topluma yansımasının bir sonucu olarak kıtlık baş gösterdi (Canşen, 2011).

\section{Anadolu'da Kıtlık}

Yarı kurak iklim bölgesinde yer alan Anadolu kuraklığa sık sık maruz kalmıştır. İklim değişiklikleri nedeniyle gelecekte de kuraklığın bu bölgeyi etkileyeceğine şüphe yoktur. MGM'ye göre, özellikle 1928, 1973, 1989, 1990, 1993, 1999, 2000, 2008 yıllarında yaygin kuraklıklar görülmüştür. Hatta 1876 y1lında yaşanan büyük kuraklık sonucunda yaklaşık 200.000 kişi hayatını kaybetmiştir (Yağc1, 2007).

Tarihte 1595 yılında başlayıp 1596 yılında etkisini tam anlamiyla gösteren k1tlk özellikle İstanbul'da sıkıntılı günlere neden olmuştur. Yağmur yağmaması nedeniyle kuraklık başlamış, çeşmeler kurumuş ve sular çekilmeye başlamıştır. Bu süreci takiben, yiyecek maddelerinin saklandı̆̆ı bundan dolayı da fiyatların arttığı kaydedilmiştir (Ürekli, 2010).

Osmanlı döneminde yaşanan kıtlık yüzünden 
çiftçilerin birçok eşkıya ile mücadele ettiği bilinmektedir. 1494 ve 1503 yılları arasında yaşanan kuraklık, veba salgınına neden olmuştur ki zaten kıtllğın devamında gelen dönemlerde birçok bulaşıcı hastalıkla mücadele verildiği kaydedilmektedir. Anadolu'da 1574-1576 yıllarında meydana gelen kıtlıktan en çok etkilenen iller arasında Adana olduğu bilinmektedir. Yine aynı vilayetimizde ve çevresinde 19 . yüzyıla gelinceye dek ciddi bir kuraklık ve devamında büyük bir kıtlık yaşandığ1 gözlenmiştir (Sarıköse, 2013). 1844 yllında yağışların yetersiz olmasından kaynaklı 1845'de tüm etkilerini göstermiştir. Osmanlı Devleti'nde halkın büyük çoğunluğu geçimini çiftçilik yaparak sağladığı için yaşanan kuraklık halkı zor durumda bırakmıştır. Kıtlıkla karşı karşıya gelinmesinin yanında su ve bitki kaynaklarının da yetersizliği insan ölümlerine yol açmıştır. Ayrıca hayvanlar da bunun bir sonucu olarak telef olmuştur. Kitlığın doğal bir uzantısı olarak salgın hastalıklar görülmeye başlanmıştır (Altındaş, 2018).

Osmanlıdönemindegörülenkıtlık olayları ekonomik ve sosyal yaşamı büyük oranda tehlikeye sokmuştur. Üstelik kıtlıklar yaşandığı dönemle kalmayıp etkisi uzun yıllar devam etmiştir. Sosyal ekonomik anlamda büyük sıkıntılara yol açmıştır. Karadeniz bölgesinde 1494 ve 1503 yılları arasında yaşanan kıtlık ve veba salgını ülkede çok ciddi sorunlara neden olmuştur. İnsanlar çok az miktarlardaki ekmeği bile çok zor şartlar altında elde etmekteydiler. Öyle ki o dönemde Bolu dolaylarında iki ay1 geçkin bir süre zarfinda ekmek bulamayan insanların “ot otladıkları” görülmüştür (Demirtaş, 2004).

İstanbul'da 1811 yllında başlayan ve 1813 yilında sona eren veba salginı halk1 büyük bir sıkıntıya sokmuştur. Yiyecek bulmada her geçen gün zorluk yaşanmaya başlandı. Tahıl kıtlı̆̆ının başlamasından sonra İstanbul halkı yaşamını sürdürmekte zorlanmaya başladı. Sonrasında meyve ve et sıkıntısı da baş gösterdi. Her şey giderek pahalanmaya başladı (Turna, 2011).

Anadolu'da yaşanan kuraklık ve kıtlıktan etkilenen yerlerden biri Çarşamba kazasıdır. Özellikle hububat üretimi ile dikkat çeken kaza 1846 ve 1874 yllarında Anadolu'da yaşanan kuraklıktan olumsuz etkilenmiştir. Misır üretimimin sıkıntıya düşmesinden dolayı kaza halkı oldukça zor günler yaşamıştır (Ünlü, 2012).

Kitlık ve peşi sıra gelen salgın hastalıklar toplumları tarih boyunca daha başka felaketlere sürüklemiştir. Kitleler halinde insan ölümlerine veya göçe neden olmuştur. XI. boyunca Anadolu halkı bu tür sorunlarla karşı karşıya gelmiştir. Yokluk ve sefalet de bu sorunun bir sonucu olarak belirmiştir. Özellikle Anadolu'da 1032-1033 yıllarında görülen şiddetli kıtlık nedeniyle insanlar kitlesel boyutta yaşamlarını kaybetmişlerdir
(Subaşı, 2015).

Birinci Dünya Savaş1 zaman1 1916'da Giresun Görele-Eynesil civarı Ruslar tarafından işgal edilmiştir. Bu olay maddi ve manevi olarak oldukça sarsıcı neticeler doğurmuştur. Kıtlık ve devamındaki salgın hastalıklar ölümlere yol açmışır (Kaya, 2018).

Ülkemiz İkinci Dünya Savaşı'na girmediği halde savaşın birçok konudaki etkilerine maruz kalmıştır. Bunlardan birisi yiyecek bulma konusundaki sıkıntı ve devamında baş gösteren kıtlıktır. Özellikle İzmir bu durumdan en çok etkilenen illerden birisidir. Konuyla ilgili birtakım tedbirler alınsa da insanların gıda maddeleri ile ilgili sıkıntıları gözlenmiştir (Öztürk, 2004). Savaşın gıda konusundaki sıkıntısını azaltmak için İzmir'deki halkevleri yiyecek yardımında bulunmuştur. Bunun yanında fiyat artıslarını denetim altına almak adına Milli Korunma Kanunu kapsamında İzmir'de öncelikle Fiyat Murakabe (Denetleme Komisyonları) kuruldu (Gökgöz, 2010). Savaş zamanında gida maddesi bulamayacağı endişesiyle insanların yiyecekleri depolamaya başlaması, tüccarların da yine aynı endişe ile fiyatların yükseleceğini düşünmesi gerçek olmuş, özellikle savaşın ortalarında fiyatlar iyice yükselmiştir (Özkurt, 2009). Savaş döneminde üretimin düşmesi özellikle ülkemiz halkının temel besin maddesi olan buğdayın üretiminin savaşın son yılında yüzde elliye yaklaşması ciddi anlamda sıkıntıya neden olmuştur. Ülke yönetimi halk1 açlıktan korumak için koruma kanunları gibi birtakım tedbirler alma yoluna gitmiştir (İnci, 2013). Yükselişe geçen fiyatlar ve kitlık için 1941 y1lında özellikle g1da konusunda sıkı kararların çıktığı Milli Korunma Kanunu hayata geçirilmiştir (Öztürk, 2013).

Su taşkınları kıtlığa neden olan doğal afetlerden birisidir. Özellikle 19. yüzyllda Konya'da su birikintilerinin tarım arazilerine dolmasından dolayı tarımsal faaliyetler dönem dönem yapılamıordu. Bu durum hem çevreye zarar veriyordu hem de bulaşıcı hastalıklara yol açıyordu. Bataklığa dönen araziler çevre için bir tehdit olduğundan yöre halkı yerel yöneticilere durumu sıklıkla bildiriyordu. Yıl içindeki kuraklık nedeniyle Konya Ovası'ndan yeterince verim alınmadığı için büyük kıtlık olayları yaşanıyordu (Muşmal, 2008).

19 yüzyıl sonlarında Anadolu'da baş gösteren kuraklık ve kıtlık, insanları yaşadıkları yerden başka yerlere göç etmeye zorunlu kilmıştır. Yerel ve merkez yöneticilerin göç edilen yerlere yardım konusunda zorluk çıkarmadıkları bilinmektedir. Özellikle Erzurum, Muş, Gümüşhane vilayetleri ile Elazığ vilayetine bağlı Palu ve Ağrı vilayetine bağlı Bayezid kazaları kuraklık ve kıtlık ile mücadele eden yerler arasında yer almıştır 
(Özger, 2008).

19. yüzyılda görülen doğal afetlerin başında kıtlık gelmekteydi. Diyarbakır bölgesi o dönemde görülen kıtlıktan dolayı oldukça sıkıntı yaşamıştır. İmkânı olmayan insanlar bölgede yaşamaya devam etmiş fakat bunun yanında göç edenler de görülmüştür. Osmanlı Devleti konuyla ilgili çözüm getirmeye çalsşsa da tüm uğraşlar geçici olmaktan çıkamamıştır (Mengirkaon, 2017).

Kuraklığın peşi sıra gelen kıtlık olayları tarihin birçok döneminde insanları zarara uğratmıştır. Batı Anadolu'da 19. yüzyılın sonu ve 20. yüzyılın başlarında gözlenen kuraklık tarımı olumsuz etkileyerek yiyecek bulma sıkıntısına yol açmıştır. Birçok insan bu nedenle başka yerlere göç etmek durumunda kalmıştır (Tekin, 2015).

\section{Kıtlık Afetine Yönelik Risk Çalışmaları}

Çalışmanın diğer bölümlerinde değinildiği üzere, kuraklık ve buna bağlı kıtlık, canlıları dönem dönem etkilemekte ve afet boyutuna ulaşabilmektedir. Aslında dünyanın var oluşundan bu yana, farklı jeolojik dönemlerde yaşanan iklim değişiklikleri, günümüzde sanayileşme ve insanın doğaya negatif müdahalesi ile hızlanmıştır.

Kontrolsüz toprak kullanımı, su kullanımı ve iklim değişiklikleri kıtlık afetini de bir risk olarak gündeme getirmektedir. Oluşan kuraklık, genellikle yetersiz beslenmeye, açlı̆̆a, salgın hastalıklara ve ölümlere neden olabilmektedir (Food and Agriculture Organization of the United Nations, 2005).

Dönem dönem ciddi kıtliklara sahne olmuş Anadolu coğrafyasında yer alan Türkiye, Hükümetler Arası İklim Değişikliği Panelinin (Intergovernmental Panel on Climate Change - IPCC'nin) Dördüncü Değerlendirme Raporunda ortaya koyulduğu gibi, iklim değişimleri sonucu ciddi şekilde etkilenebilecek olan Akdeniz Havzasında yer almaktadır (IPCC, 2012). Resim 2 ve 3'de MGM tarafindan hazırlanan, Türkiye'nin 19402010 ve 2017-2019 y1llarına ait alansal kuraklık haritas1 sunulmuştur.

Türkiye bu nedenle, "Türkiye Tarımsal Kuraklıkla Mücadele Stratejisi ve Eylem Planı” (2008-2012) ve (2018-2030)'u uygulamaya koymuştur. Ancak, Türkiye'de “İklim Risk Yönetimi” çerçevesinde iklim değişimiyle ilgili politika, planlama ve uyum programlarının afet risk yönetimi stratejisiyle bütünleştirilmesi gerekmektedir (Afet Yönetiminde Etkinlik T.C. Kalkınma Bakanlı̆g Özel İhtisas Komisyonu Raporu Ankara, 2014, URL 3). Afet risk yönetimi ve iklim değişikliği stratejisi Resim 4'te sunulmuştur.

Daha etkin bir kuraklık yönetimi sağlanabilmesi için kuraklık öncesini, esnasını ve sonrasını bir bütün olarak ele alan risk tabanlı yönetim stratejilerinin uygulanması gerekmektedir. Kuraklık Öncesinde, nehir havzasinın karakteristikleri ve arazi kullanımı dikkate alınarak kuraklık şiddetinin belirlenmesinde kullanılacak kuraklık indisi ve göstergelerinin belirlenmesi, Kuraklık tahmin ve erken uyar1 sistemlerinin oluşturulması, Her havza için kuraklık haritaları ve kuraklık yönetim planlarının hazırlanması veya geliştirilmesi, kuraklık envanterinin oluşturulması ve geliştirilmesi, tarımsal ürün verimi sigorta sisteminin hazırlanması ve geliştirilmesi, suyun tasarruflu kullanılmasına yönelik eğitim faaliyetlerinin yapılması, kuraklık esnasında uygulanmak üzere kurum ve kuruluşlara ait acil eylem planlarının hazırlanması, havzalar arasi su transferi projelerinin hazırlanmasi aşamasında havzada yaşanmış kuraklıkların göz önünde bulundurulması, hidrolojik izleme istasyonlarının, tahmin ve izleme sistemlerinin kurulması, tarımsal sulama sistemlerinde su tasarrufu sağlayan modern sulama sistemlerine geçilmesi, Su iletim ve dağıtım sistemlerinde kayıp ve kaçakların mümkünse önlenmesi veya azaltılması gerekmektedir (Ulusal Kuraklık Yönetimi Strateji Belgesi ve Eylem Plan1 2017-2023, URL 1).

Kuraklık afetini deprem gibi diğer doğal afetlerden ayıran en önemli özellik, başlangıç ve bitiş zamanının kesin bir şekilde tespit edilmesinin çok zor olmasıdır. $\mathrm{Bu}$ sebeple kuraklık afetinin zararlarını azaltmak ve gerekli tedbirleri alabilmek için öncelikle erken uyarı sistemleri geliştirilmesi gerekmektedir. Sadece yağışlara ve tarımsal kuraklığa değil; yağışla birlikte akım, yer altı su seviyesi gibi faktörlere göre, hidrolojik ve sosyoekonomik kuraklıklar da izlenmeli ve alınacak önlemler belirlenmelidir (Tablo 1).

Ayrıca, kuru tarım alanlarındaki kuraklık riskinin sulu tarım alanlarındakinden daha yüksek olması nedeniyle olası kuraklık döneminde, özellikle temel ürünlerin üretim tahminlerinin yapılması gerekmektedir (URL 1).

Kıtlık göstergelerinden olan, farklı tarımsal ürün büyüme aşamaları ekim ve çiçeklenme süreçlerinin izlenmesi de önemlidir. Kutluğın sürekli izlenmesi riskin yönetilmesi ve planlamaların yapılması açısından gereklidir.

Kıtlık zamanı genelde, hükümetler kriz yönetimi uygularken, halk ise geleneksel çözüm yöntemleri aramaktadırlar. Örneğin, Çin'de yaşanan büyük kıtlığa ilişkin yöre halkıyla yapılan anketler, kıtlıkla mücadele etmek için; halkın \%84'ünün yabani sebzeler, meyveler ve kökler toplayıp tükettiğini, \%10'dan fazlasının ise başka yerlere göç ettiğini göstermektedir. Kıtlık 


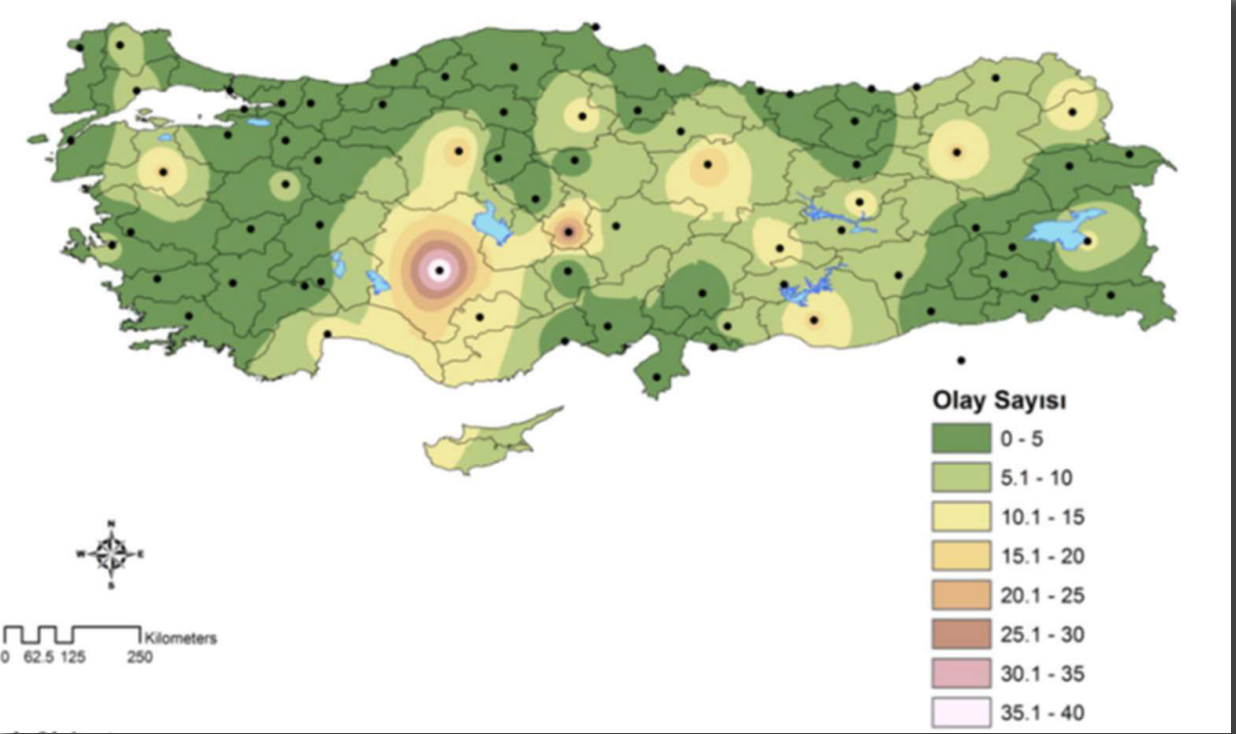

Resim 2. Türkiye'de 1940 - 2010 yılları arasında afete neden olan kuraklık olaylarının alansal dağılımı (URL 2).

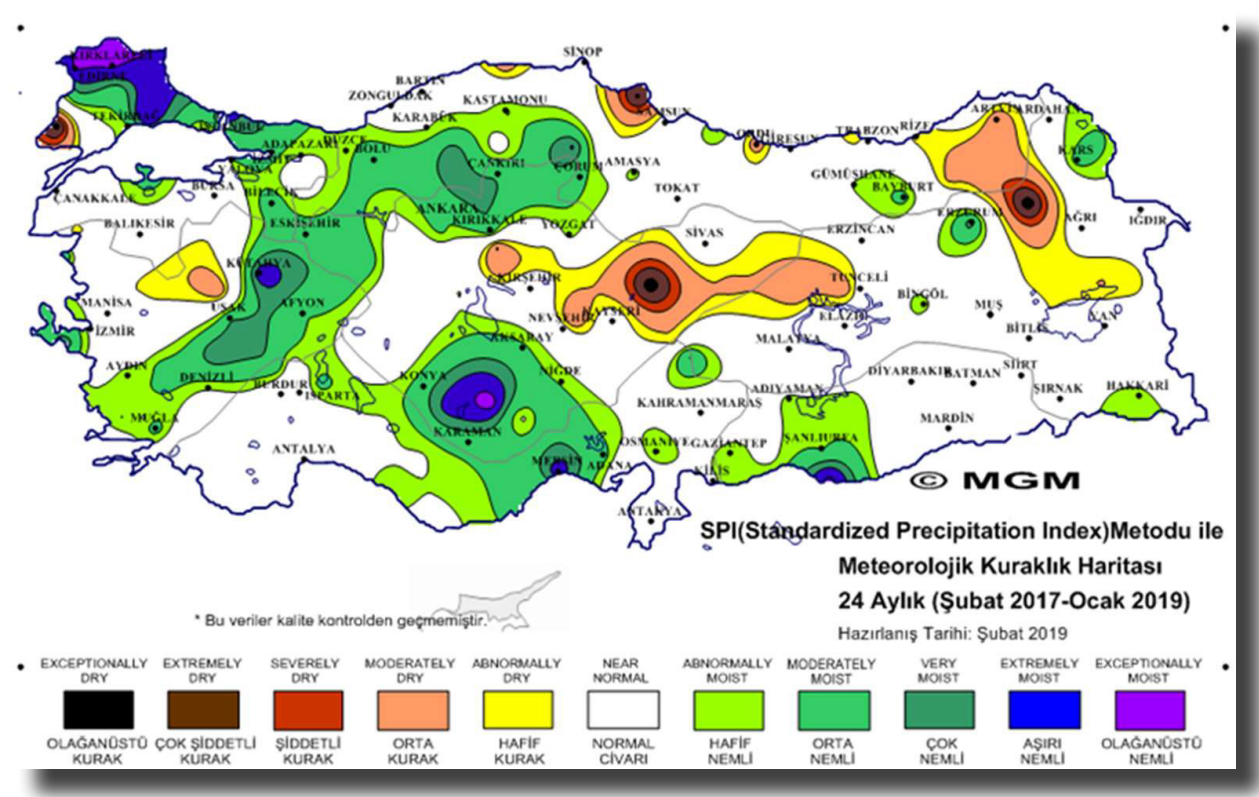

Resim 3. Türkiye'de 1940 - 2010 yılları arasında afete neden olan kuraklık olaylarının alansal dağılımı (URL 2).

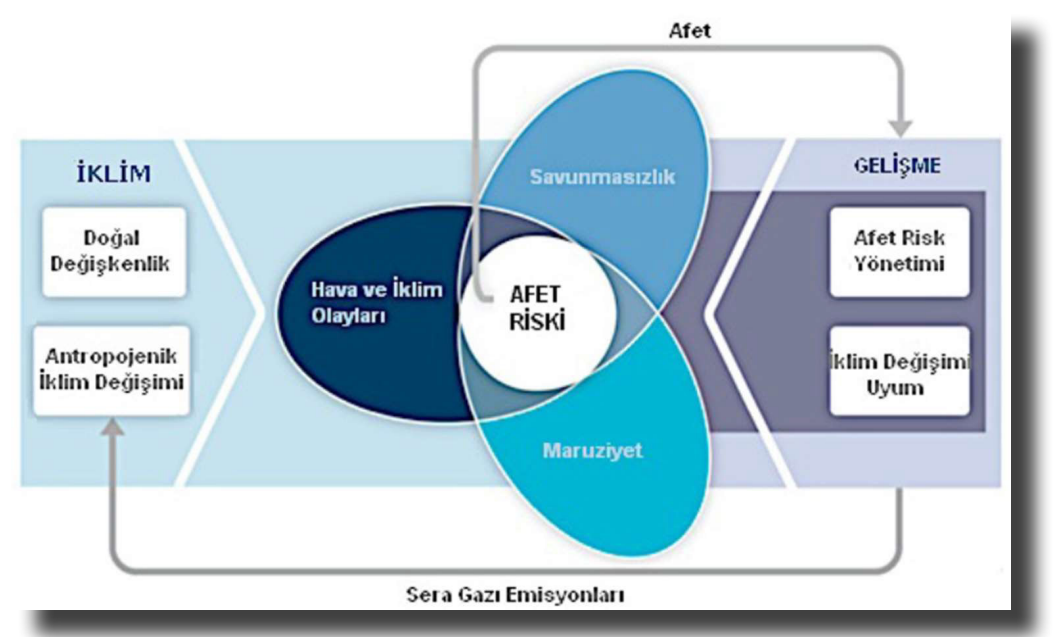

Resim 4. İklim Değişikliğine Uyum ve Afet Risk Yönetimi ile İlişkilendirilmesi (IPCC, 2012). 
Tablo 1. Kuraklık izlemesinde kullanılacak hidro-meteorolojik parametreler ve alarm seviyeleri (Kadığlu, 2012).

\begin{tabular}{|c|c|c|c|}
\hline & İzleme & Uyarı & Acil \\
\hline $\begin{array}{l}\text { Yağış eksikliği (12 aylık } \\
\text { kuraklık süresince) }\end{array}$ & Normal yağıştan \%15 (eksik) & Normal yağıştan \%25 (eksik) & Normal yağıştan \%35 (eksik) \\
\hline Akımlar & $\begin{array}{c}30 \text { günlük ortalama akım } \\
\text { bu zamanın \%75’i boyunca } \\
\text { düşük oldu }\end{array}$ & $\begin{array}{c}30 \text { günlük ortalama akım } \\
\text { bu zamanın \%90’1 boyunca } \\
\text { düşük oldu }\end{array}$ & $\begin{array}{c}30 \text { günlük ortalama akım } \\
\text { bu zamanın \%95’i boyunca } \\
\text { düşük oldu }\end{array}$ \\
\hline Yeraltı Su Seviyesi & $\begin{array}{c}30 \text { günlük ortalama seviye } \\
\text { bu zamanın \%75’i boyunca } \\
\text { düşük oldu }\end{array}$ & $\begin{array}{c}30 \text { günlük ortalama seviye } \\
\text { bu zamanın \%75’i boyunca } \\
\text { düşük oldu }\end{array}$ & $\begin{array}{c}30 \text { günlük ortalama seviye } \\
\text { bu zamanın \%95’i boyunca } \\
\text { düşük oldu }\end{array}$ \\
\hline $\begin{array}{l}\text { Toprak Nemi - Palmer } \\
\text { Kuraklık Şiddet Endeksi }\end{array}$ & Değer -2.00 ile -2.99 & Değer -3.00 ile -3.99 & Değer -4 veya daha az \\
\hline Olası Önlemler & $\begin{array}{l}\% 5 \text { ile } \% 10 \text { arasinda gönüllü } \\
\text { su tasarrufu }\end{array}$ & $\begin{array}{l}\% 10 \text { ile } \% 15 \text { arasinda } \\
\text { gönüllü su tasarrufu }\end{array}$ & $\begin{array}{l}\text { Gereksiz su kullanıminda } \\
\text { zorunlu kisitlama }\end{array}$ \\
\hline
\end{tabular}

sonrası halkın büyük çoğunluğu sağlıklarını kaybetmiş, yoksullaşmış, sosyalliklerinde azalma olmuş, kötü hasat almışlar, su sıkıntısı çekmişler ve önemli oranda hayvan ölümleri yaşanmıştır (Fernández-Giménez vd., 2015).

Kuraklık öncesi göstergeler, rüzgârın kuru esmesi, uzun süren sıcak dönemler, düzensiz ve yetersiz yağmur ve yapraklarda kuruma olarak gelişebilir. Kuraklığın etkilerinin azaltılmasında, geniş kapsamlı afet risk yönetimi uygulaması ve planlama önemlidir. Kuraklığın birçok parametre ile izlenmesi risk yönetimini başarılı k1lacaktır.

\section{Sonuç}

Tarihin eski dönemlerinden itibaren insanoğlu yaşamını sürdürebilmek adına temel gida maddelerini temin etmek için büyük bir mücadele sürdürmüştür. Bu anlamdaki istikrarı da bir düzen içinde sağlaması gerekmekteydi. Fakat gerek doğal gerekse beşerî nedenler yüzünden toplumlar kıtlık afeti ile karşı karşıya gelmiştir. Çeşitli iklimsel sorunlar, ekonomik ve siyasi nedenlerden insanlar yiyecek bulmakta zorlanmış ve yaşanan kıtlık nedeniyle tarihin belirli dönemlerinde sayısız insan yaşamını yitirmiştir. Yöneticilerin aldığı tedbirler kimi zaman sikıntının boyutunu azaltsa da kimi zaman da hiçbir işe yaramayıp halkların ciddi anlamda zorluk çekmesine yol açmıştır.

İnsan eli ile müdahale edilemeyen doğa olayları ya da savaşlardan sonra yaşanan kıtlık ile ilgili mücadelede, yöneticilerin geleceğe yönelik planlar yapması yerinde olacaktır. Çünkü kıtlık tek başına bir afet olmayıp devamındaki süreçte de salgın hastalıklar ya da ölümler gibi felaketlere yol açabilmektedir.

Kıtlık afeti ile başa çıkabilmek için, çok disiplinli bir yaklaşımı gerektiren, afet çalışmaları hem teknik hem de sosyal bilimler bakış açısı ile yürütülmelidir. Orman, toprak, su kaynakları koruma planları, ağaçlandırma kuraklığın etkilerini azaltabilecek, kuraklık ve çölleşme süreçlerinin izlenmesi ise önlemlerin artırılmasında etkin olacaktır.

\section{Kaynakça}

Altındaş, T. E. (2018). 19. Yüzyılda Osmanlı Devleti'nde Yaşanan Kuraklığın Ankara'ya Yansıması, Canakekale Arastırmalar Türk Yillĭg, 16(24), 1-13.

Aybar, M. (2017). Osmanlı Devletinde Kıtlık ve İç Göç: 1870-1900 Arası İç Anadolu Örneği, Mavi Atlas, 5(2), 474-488.

Baygıner, A. N. (2013). 20. Yüzynl Savaşlarmm Sosyal Yaşantıya ve Kıyafetlere Yansımalar, Beykent Üniversitesi Sosyal Bilimler Enstitüsü Tekstil ve Moda Tasarımı Anasanat Dalı Tekstil ve Moda Tasarımı Sanat Dalı, Yayımlanmamış Yüksek Lisans Tezi, İstanbul.

Beşirli, H. (2017). Yemek Sosyolojisi: Yiyeceklere ve Mutfağa Sosyolojik Bakış. Ankara: Phoenix Yayınevi.

Canşen, E. (2011). Sovyetler Birliği'nden Rusya Federasyonu'na Doğru Değişimin Yan Etkileri, Süleyman Demirel Üniversitesi Fen-Edebiyat Fakültesi Sosyal Bilimler Dergisi, 24, 79-111. 
Demir, A. ve Aktaş, E. (2008). Gümüşhane Sancağı'nda Doğal Afetler (1888-1910), Ankara Üniversitesi Osmanl Taribi Araştırma ve Uygulama Merkezi Dergisi, 24, 21-54.

Demirtaş, M. (2004). XVI. Yüzyılda Meydana Gelen Tabii Afetlerin İstanbul'un Sosyal Ve Ekonomik Hayatına Etkilerine Dair Baz1 Misaller, Atatürk Üniversitesi Sosyal Bilimler Enstitüsü Dergisi, 4(2), 37-50.

Fernández-Giménez, M. E., Batkhishig, B., Batbuyan, B., ve Ulambayar, T. (2015). Lessons from the dzud: Communitybased rangeland management increases the adaptive capacity of Mongolian herders to winter disasters, World Development, $68,48-65$.

Food and Agriculture Organization of the United Nations (2005). Global Information and Early warning system. 24 sub-Sabaran Afric an countries face food emergencies. Africa Report, Rome.

Goody, J. (2013). Yemek, Mutfak ve Simf, Karşılaştırmal Sosyoloji Çalısması, M. G. Güran (Çev.), İstanbul: Pinhan Yayıncılık.

Gökgöz, G. (2010). 2. Dünya Savaşı Yillarında İzmir'de Gıda Ticareti ve Yașanan Bunalım, Dokuz Eylül Üniversitesi Atatürk İlkeleri ve İnkılâp Tarihi Enstitüsü Yayınlanmamış Yüksek Lisans Tezi, İzmir.

Gökşenli, E. Y. (2013). İç Savaş ve Savaş Sonrası İspanyası'nın İlk Döneminde Toplumsal Değişim, Istanbul Üniversitesi Sosyoloji Dergisi, 3(26), 145-170.

Gürsoy, D. (1995). Yemek ve yemekçiliğin evrimi, Kurtiş Matbaacilık.

IPCC (2012). Managing the risk of extrem events anad disasters to advence climate change adaptation, IPCC Special Report.

İnci, İ. (2013). İkinci Dünya Savaşı Yılların Türkiye'de Tek Parti Hükümetlerinin İaşe Politikalar1, Türkiyat Araştırmalan Enstitüsü Dergisi, 50, 271-290.

Kadıŏ̆lu, M. (2012). Türkiye'de İklim Değisilkliği Risk Yönetimi, Türkiye'nin İklim Değişikliği II. Ulusal Bildiriminin Hazırlanması Projesi Yayını, 172.

Kalemli, H., ve Erdem, U. (2011). II. Dünya Savaşı Sırasında Türkiye'nin Yunanistan'a Kurtuluş ve Dumlupınar Vapurları İle Gönderdiği İnsani Yardımlar, A. Ü. Türkiyat Arastırmalar Enstitüsü Dergisi, 46, 205-236.

Karademir, Z. (2013). Osmanl Imparatorluğu'nda Darlı Ekonomisi ve Kitlkelar (1560-1660), Cumhuriyet Üniversitesi, Sosyal Bilimler Enstitüsü, Tarih Anabilim Dalı/Yeniçağ Tarihi Bilim Dalı, Yayımlanmamış Doktora Tezi.

Kaya, M. (2018). I. Dünya Savaşı'nda Eynesil Yöresinde Rus İsgalinin Anılara Yansımaları, Stratejite ve Sosyal Araștırmalar Dergisi, 2(3), 47-68.

Mengirkaon, S. (2017). Osmanlı'da Sosyal Devlet ve Kriz Yönetimi: 19. Yüzyıl Diyarbakır'ında Kıtlık, Kadim Akademi Sosyal Bilimler Dergisi, 1(2), 139-155.

Merdol, T. K. ve Merdol, A. (2012). Küreselleşmenin Beslenme Biçimine Etkilerinin Tarihsel Gelişim Bakış Açısı İle Değerlendirilmesi, T. K. Merdol (Ed.) içinde, Beslenme Antropolojisi I, Ankara: Hatipoğlu Basım ve Yayım.

Montanari, M. (2018). Kıtllk ve Bolluk, M. Önen ve B. H. Çoban (Çev.), Ankara: Nika Yayınevi.
Muşmal, H. (2008). XX. Yüzyılın Baslarında Beyşehir Gölü ve 1910-1911 Y1lları Büyük Taşkın Hadiseleri, Türkiyat Arasttrmalar Dergisi, 23, 219-262.

Nişanc1, A. (1987). Türkiye'nin Kurak ve Nemli Sahaları. Ondokuz. Mayıs Üniversitesi Eğitim Fakültesi Dergisi, 2(1), 59-66.

Obuz, Ö. (2017). Cumhuriyet Döneminde Çetin Bir Mücadele: Çekirge İle "Savaş". Turkish Studies International Periodical For The Languages, Literature And History of Turkish or Turkic, 12(1), 177-190.

Onaran, B. (2016). Mutfaktarih, Yemeğin Politik Serüvenleri, İstanbul: İletişim Yayınları.

Özkurt, E. (2009). İkinci Dünya Savaşı Döneminde Tarm Politikası, Yeditepe Üniversitesi Atatürk İlkeleri ve İnk1lap Tarihi Enstitüsü Yayınlanmamış Yüksek Lisans Tezi, İstanbul.

Özger, Y. (2008). XIX. Yüzyıl Sonlarında Meydana Gelen Bir Kuraklık ve Kıtlık Hadisesi İle Bunun Sosyo-Ekonomik Sonuçları, Karadeniz. Arastırmalar Dergisi, 19, 87-96.

Öztürk, E. (2004). İkinci Dünya Savaşı Yıllarnda İzmir'de Beslenme Sorunu ve Karaborsacllk, Dokuz Eylül Üniversitesi Atatürk İlkeleri ve İnkılap Tarihi Enstitüsü Yayınlanmamış Yüksek Lisans Tezi, İzmir

Öztürk, İ. M. (2013). İkinci Dünya Savaş1 Türkiye'sinde Olağanüstü Ekonomik Kararlar: Milli Korunma Kanunu ve Varlık Vergisi, Tarih Araștormalan Dergisi, 32(54), 135-166.

Sarıköse, S. T. (2013). XIX. Yüzynlda Cukurova'da Doğal Afetler ve Salgın Hastalıklar, Selçuk Üniversitesi, Sosyal Bilimler Enstitüsü, Tarih Ana Bilim Dalı, Yakınçağ Tarihi Bilim Dalı, Yayımlanmamış Doktora Tezi.

Standage, T. (2016). İnsanlĭgn Yeme Taribi, Maya Kitap, İstanbul.

Subaşı, Ö. (2015) XI. Yüzyılda Anadolu'da Meydana Gelen Doğal Afetler, A. Ü. Türkiyat Araştırmalar Enstitüsü Dergisi, 54, 505535.

Taşdöner, K. (2012). Eski Çağ’da Anadolu'nun Siyasi ve Demografik Yapısını Değiştiren Kitlesel Göçler, Çanakkale Araştırmalar Türk Yillĭğ, 13, 85-103

Tekin, S. (2015). 19. Yüzyılın Sonu 20. Yüzyllın Başlarında Batı Anadolu'da Yaşanan Kuraklık Olayları, International Journal of Social Science, 33, 329-341.

Turna, N. (2011). İstanbul'un Veba İle İmtihanı: 1811- 1812 Veba Salgını Bağlamında Toplum ve Ekonomi, Studies of the Ottoman Domain, 1(1), 1-36.

Utkugün, C. (2016). İkinci Dünya Savaşı Yıllarında Türkiye'den Yunanistan'a Yapılan İnsani Yardım Faaliyetleri, Afyon Kocatepe Üniversitesi Sosyal Bilimler Dergisi, 18(2), 199-219.

Ünlü, M. (2012). XIX. Yüzyıl Sonlarında Çarşamba'da Kuraklık, Karadeniz Incelemeleri Dergisi, 6(12), 125-132.

Ürekli, F. (2010). Osmanlı Döneminde İstanbul'da Meydana Gelen Âfetlere İlişkin Literatür, Türkiye Araștırmalar Literatür Dergisi, 8(16), 101-130.

Yağc1, B. (2007). İklim Değişikliği ve Kuraklik Analizi. Devlet Meteoroloji İşleri Genel Müdürlüğü. 
Yıldırım, M. A. (2014). Birinci Dünya Savaşı Yıllarında Osmanlı Devleti'nin Beşinci Düşmanı: Çekirgeler. Gą̧iantep University Journal of Social Sciences, 13(4), 1017-1042.

Yllmaz, F. B. U. (2010). 20. Yǚyllda Savaşlarn Uzun Dalgalar ve Sinai Cevrelerdeki Etkileri, İstanbul Üniversitesi Sosyal Bilimler Enstitüsü Maliye Anabilim Dalı, Yayınlanmamış Doktora Tezi, İstanbul.

\section{Çevrimiçi Kaynakça}

URL 1: Ulusal Kuraklık Yönetimi Strateji Belgesi ve Eylem Planı 2017-2023 (Son Erişim Tarihi: 10.03.2019) https:// www.tarimorman.gov.tr/SYGM/Belgeler/Ulusal\%20 Kurak1\%C4\%B1k\%20Y\%C3\%B6netimi $\% 20$ Strateji $\% 20$ Belgesi $\% 20 v e \% 20$ Eylem $\% 20 \mathrm{Plan} \% \mathrm{C} 4 \% \mathrm{~B} 1 / \mathrm{Ulusal} \% 20$ Kurakl $\%$ C4\%B1k\%20Y\%C3\%B6netimi $\% 20$ Strateji $\% 20$ Belgesi $\% 20 v e \% 20$ Eylem $\% 20 \mathrm{Plan} \% \mathrm{C} 4 \% \mathrm{~B} 1$.pdf

URL 2: (Son Erişim Tarihi: 10.03.2019) https://www.mgm.gov.tr/ veridegerlendirme/kuraklik-analizi.aspx

URL 3: Afet Yönetiminde Etkinlik T.C. Kalkınma Bakanlığ1 Özel İhtisas Komisyonu Raporu (2014). (Son Erişim Tarihi: 10.03.2019) $\quad$ http://www.cka.org.tr/dosyalar/Ozel $\% 20$ Ihtisas $\% 20$ Komisyonu $\% 20$ Raporlar $\%$ C $4 \%$ B1/ Afet $\% 20$ $\mathrm{y} \% \mathrm{C} 3 \% \mathrm{~B} 6$ netiminde $\% 20$ etkinlik $\% 20 \% \mathrm{C} 3 \% \mathrm{~B} 6 \mathrm{ik} \% 20$ raporu. pdf 